\title{
CIVILIDADE E EMPATIA EM DISPUTA: O PROBLEMA DO CONTROLE DE ANIMAIS NO ESPAÇO PÚBLICO
}

\author{
Maria Helena Costa Carvalho de A. Lima ${ }^{1}$ \\ Simone Magalhães Brito ${ }^{2}$
}

As espécies de estimação nas grandes cidades brasileiras têm cada vez menos oportunidade para corridas e travessuras ou para cavar, coçar, cheirar e brincar em ambientes amplos e sem supervisão. Não se trata apenas de falta de espaço, mas também das consequências de mais de um século de associação entre animais soltos e perigo - seja para as pessoas, seja para eles mesmos. Nos grandes centros urbanos brasileiros, ver um cão correndo solto na rua gera duas emoções negativas: medo de sofrer um ataque e angústia de que o animal seja atropelado. No caso dos felinos, tradicionalmente representados como irredutivelmente livres, tais emoções também estão presentes, mas o primeiro tipo de medo não é tanto de agressão, e sim de contaminação por alguma das doenças a eles atribuídas. A convivência entre animais humanos e não humanos no espaço público é marcada por uma grande tensão entre emoções e moralidades divergentes. Aqui buscamos analisar, a partir do caso de Recife (PE), as disputas morais que permeiam a ocupação do espaço público por animais não humanos. Mais especificamente, discutimos como os processos de ordenação dessa convivência são permeados por valores conflitantes, mas igualmente submetidos a um imperativo de controle das emoções. Assim, percebemos a produção uma sensibilidade particular que, apesar de tensa e precária em seus acordos, tem fundamentado a construção de uma base normativa para a convivência interespécie no espaço público.

Com o crescimento das cidades, os cães e gatos multiplicaram-se muito rápido e, especialmente a partir do século XX, essas populações tornaram-se tão grandes que a Organização Mundial de Saúde (OMS) passou a recomendar o extermínio de animais errantes como medida sanitária, especialmente no combate à raiva (WHO/OMS, 1949; idem, 1973) ${ }^{3}$. Entre os impactos da política de captura e morte, destaque pode ser dado ao estabelecimento de uma distinção radical entre animais "especiais" e "sem valor".

\footnotetext{
${ }^{1}$ Universidade Federal de Pernambuco, Brasil.

${ }^{2}$ Universidade Federal da Paraíba, Brasil.

${ }^{3}$ Epidemias de raiva e peste bubônica já haviam sido combatidas com extermínio de cães, gatos, ratos e mesmo de grupos humanos (Rezende, 2009, Ritvo, 2003 Thomas, 2010), mas foi no século XX que essa
} 
Ao mesmo tempo em que, por séculos, estimularam o afastamento em relação aos animais não humanos, os impulsos civilizadores ${ }^{4}$, tiveram nessa figuração um de seus tantos efeitos ambíguos, pois o incômodo civilizado com a dor e a morte gradativamente passou a abarcar cães e gatos no círculo de seres cujo sofrimento abala emocionalmente os humanos (Ritvo, 2003). Como resultado de uma moralidade civilizada, as políticas de captura e morte desde a década de 1970 foram cada vez mais regradas pela busca por um tratamento humanitário. Assim, de forma não planejada, o incômodo civilizado com as expressões de sofrimento dos animais errantes estimulou uma suavização da dicotomia entre cães e gatos "especiais" e "sem valor", dado que estes já não poderiam ser exterminados como "meros animais". Como se pode observar, tivemos, num curto espaço de tempo, uma mudança expressiva na forma como se fundamenta o tratamento dos animais não humanos no espaço público. Propomos que essas variações na economia de valores atribuídos às espécies não humanas precisam ser entendidas a partir de uma ordem de interação ou figuração.

Das demandas humanitárias, que apenas suavizavam e disfarçavam o extermínio, à condenação da captura e morte como crueldade, tivemos a constituição de ordens normativas significativamente distintas, que precisam ser consideradas em seu processo de formação se quisermos compreender o atual contexto de sociabilidade entre humanos e animais de estimação. Conforme traçado em maiores detalhes por Lima (2016), é possível perceber que as mudanças recentes nas políticas de manejo de cães e gatos são decorrentes de uma figuração peculiar, formada pela expansão das emoções civilizadas, pela emergência da sensibilidade de empatia interespécie e pela mudança nas orientações técnicas da OMS. Para que possamos analisar como civilidade e empatia se encontram e formam tensas operações de compromisso, vale a pena nos determos mais um pouco nos elementos constituintes de tal figuração.

medida foi oficializada e indicada para o mundo todo por uma organização de abrangência internacional. Nas Américas, a raiva chegou no século XIX e tornou-se epidêmica no século XX.

${ }^{4}$ Falamos em civilidade seguindo a teoria do Processo Civilizador de Norbert Elias (1993, 1994, 2001, 2011). Trata-se de uma transformação de longo prazo nas estruturas sociais e nas estruturas de personalidade que, na Modernidade, culminou no desenvolvimento de uma sociedade de indivíduos submetidos a um controle constante da conduta e das emoções. Em outros termos, trata-se de um processo de moldagem e controle da sensibilidade ou da vida instintual em função de uma lógica de interdependência. É importante esclarecer que o uso do termo civilizado pela sociologia figuracional não é uma adoção acrítica do sentido de superioridade moral que alimentou o imperialismo europeu, e sim a identificação do conjunto de ações particulares, os fundamentos práticos da ordem social e psíquica que levaram europeus a se perceberem como moralmente superiores. Elias, portanto, não discute uma suposta evolução moral do Ocidente, mas a formação de um habitus particular que permite aos seus detentores se perceberem como moralmente superiores e/ou se dizerem civilizados. 
Em 1988, após a realização de estudos sistemáticos sobre manejo de populações caninas, a OMS chegou às seguintes conclusões: 1 - devido à alta taxa de reprodução dessas espécies, o extermínio é ineficaz para o controle populacional; 2 - o extermínio gera resistência em algumas comunidades, que dificultam o trabalho dos agentes de controle; 3 - uma política de castração e vacinação, ao invés de extermínio, é mais eficaz para promover a saúde pública e engajar a população (OMS, 1988; OMS, 1992). Esse parecer técnico forneceu legitimidade para a demanda, até então minoritária, de que os governos abolissem a prática do extermínio.

Nessa nova figuração, os grupos de proteção animal começaram a ganhar força e a serem reconhecidos como importantes, dado que se incumbiram de realizar medidas de controle populacional, buscar domicílio para animais errantes e educar os tutores em relação a cuidados sanitários. Nos grandes centros urbanos, o extermínio de animais em situação de rua, antes entendido como necessidade inquestionável, aos poucos passou a gerar emoções negativas e a ser rechaçado como crueldade desnecessária e, inseridos nessa figuração, a mídia e o poder público têm incorporado gradativamente alguns dos princípios apregoados pela proteção animal (Osório, 2013). É nesse cenário que ocorre a expansão da sensibilidade de empatia interespécie, caracterizada pela percepção de certas espécies animais como dignas de consideração moral e de seus membros como indivíduos dotados de sensibilidade, vida mental, preferências e afetos. As redes de interações e experiências mobilizadas pela sensibilidade de empatia interespécie formam uma base a partir da qual tem ocorrido o crescimento dos movimentos de proteção animal e de reivindicações apoiadas por um conjunto cada vez mais amplo da população. Em meio a esse processo, a condenação do extermínio de animais errantes pode ser percebida como um marco fundamental para a reconstrução da experiência com animais não humanos no espaço público das grandes cidades.

Embora esteja se fortalecendo, a sensibilidade de empatia interespécie disputa centralidade na ordenação de valores com uma lógica de interação estabelecida há mais tempo: aquela baseada numa hierarquia rígida entre humanidade e animalidade (Ingold, 1995; Thomas, 2010). Essa lógica tradicional, estabelecida por uma sensibilidade antropocêntrica, parte do princípio de que os interesses e o bem-estar humanos são necessariamente mais importantes que os de outras espécies, de maneira que se torna legítimo usar, confinar e matar animais não humanos nas mais diversas circunstâncias (Lawrence, 1994; Regan, 2006; Singer, 2010). A exigência de cuidados humanitários 
ressalte-se, não é uma quebra com a lógica antropocêntrica, e sim uma extensão da própria lógica do processo civilizador.

Não é possível dar conta de todos os elementos que contribuíram para essa nova ordem de valores, uma vez que tal abordagem iria requerer uma explicação ampla das bases normativas que orientam a experiência contemporânea. Contudo, acreditamos que seja possível lançar luzes sobre o problema da relação moral entre animais humanos e não humanos no espaço público a partir de uma análise das ambiguidades geradas pela combinação entre a sensibilidade de empatia interespécie e uma sensibilidade civilizada, entendidas a partir da experiência de proibição da política de extermínio em Pernambuco. Nesse sentido, destacamos o papel do medo e do nojo persistentes, especialmente em relação aos animais em situação de rua. As emoções persistentes de medo e nojo no contato com cães e gatos são trazidas como exemplo do caráter limiar da civilidade em relação à violência e do contraste entre as expressões morais antropocêntricas e as moralidades fundadas na sensibilidade de empatia interespécie. Após estabelecer a distinção entre a moralidade civilizada e a moralidade de proteção, retomamos o ponto de confluência entre elas, qual seja a intenção de restringir e controlar a circulação de cães e gatos no espaço público e de civilizar as relações travadas com esses animais.

\section{Aspectos metodológicos}

Os dados em que se baseia esse artigo são parte de uma pesquisa mais ampla, que teve como objetivo reconstruir a figuração que permitiu o surgimento de uma sensibilidade de empatia interespécie (Lima, 2016). Seguindo Elias, entendemos figuração como uma rede de interações que só pode ser compreendida a partir de seu fluxo histórico. Portanto, partimos de uma tentativa de reconstituição do movimento e das transformações, que relacionamos como uma forma da civilidade, no modo de relacionamento entre espécies humanas e não humanas no espaço urbano. Desse modo, buscamos compreender o impacto do processo civilizatório nas relações interespécie através das seguintes etapas: 
1- Observação participante realizada a partir da inserção no Programa Adote um Vira-Lata (UFPE), que envolveu a participação em 20 eventos de adoção e 14 mutirões de castração, entre 2013 e 2015. Além dos eventos deste programa, também foram frequentados protestos, audiências públicas e reuniões de protetores no período citado.

2- Identificação de leis e projetos de lei que versam sobre cães e gatos (utilizando os mecanismos de busca de diversas casas legislativas).

3- Mapeamento de notícias, notas, colunas e cartas de leitores publicados nas edições de sábado e domingo dos jornais pernambucanos Diário de Pernambuco e Jornal do Commercio, no período de janeiro de 2009 a março de 2012.

4- Acompanhamento das publicações realizadas nos grupos virtuais SOS Adoção Recife, Adote um Bichano e Vegetarianos e Veganos Recife.

5- Pesquisa quantitativa de mapeamento, realizada em 2011, com 98 protetores de animais da Região Metropolitana do Recife.

6-Aplicação de 546 questionários aplicados com as pessoas que adotaram cães ou gatos com o Programa Adote um Vira-Lata, entre os anos de 2013 e 2014.

7- Consulta a 15 edições de revistas especializadas em animais de estimação: Revista Cães \& Companhia (posteriormente nomeada Cães \& Cia), revista Cães e revista Cães \& Raças, datadas dos anos de 1981 a 1996.

O cruzamento dos dados buscou seguir a metodologia eliasiana no que tange à aproximação e confronto de dados variados, organizados em torno da reconstrução dos processos históricos de transformação das sensibilidades e valores. Por fim, foram consultados documentos físicos e virtuais produzidos por protetores ou simpatizantes da causa com a intenção de ordenar as ações dos tutores - que aqui chamamos genericamente de "manuais de guarda responsável" pela sua semelhança com os manuais de civilidade estudados por Elias.

A discussão apresentada neste artigo é um recorte particular do conjunto de dados indicados acima, numa leitura focada especificamente nos tensionamentos da ordem de valores estabelecida a partir do debate sobre a presença dos animais no espaço público, por isso, ao invés de escolher um único conjunto de dados para basear o artigo, buscamos o que cada tipo de dado trouxe de mais relevante para que se demonstre a figuração em que emergem as questões aqui apresentadas. 


\section{Mudanças na convivência e na política de controle populacional de cães e gatos}

No Brasil, as emoções negativas associadas ao contato com os corpos animais são reforçadas pelo fato de que a convivência humana com cães e gatos foi quase exclusivamente instrumental até o século XIX (Godinho, 2010; Heynemann, 2010). Enquanto predominou a atribuição de funções de trabalho para os cães, o padrão de criação, tanto no ambiente rural quanto no urbano, foi manter os animais nas áreas externas da casa, alimentá-los com restos de refeições e sacrificá-los quando envelhecessem, sofressem acidentes ou apresentassem doenças com tratamento custoso ou demorado (inclusive infestação por parasitas).

Apesar desse padrão de distanciamento físico e apego emocional instável, o status dos animais de estimação aumentou paulatinamente, até que se passou a valorizar as espécies canina e felina como úteis e agradáveis para os humanos. Esse processo foi fortemente impulsionado pelo mercado pet, que estimulou a atenção para o comportamento e a beleza atribuídos a determinadas raças ${ }^{5}$. Ao longo do século XX, a valorização dos cães de raça e a popularização de seu uso para a função de guarda gerou efeitos contraditórios. Por um lado, a expansão desse mercado estimulava um olhar de admiração sobre eles; por outro lado, o uso desses animais como instrumentos de defesa e ameaça estimulava também um olhar de desconfiança.

Embora o afastamento físico tenha sido o padrão adotado no Brasil desde os tempos coloniais, o medo e o nojo do contato com os animais de estimação podem ser explicados a partir de uma história mais recente. A partir da década de 1960, o Brasil passou por epidemias zoonóticas de raiva e leishmaniose, que ganharam a forma de pânico moral e passaram a ser combatidas com o extermínio de animais em situação de

\footnotetext{
${ }^{5} \mathrm{Na}$ discussão mais ampla sobre a figuração que possibilita o desenvolvimento da empatia interespécie (Lima, 2016) o mercado pet apresenta um papel fundamental. Porém, apesar de sua relevância para a constituição da sensibildade que aproxima humanos e não humanos, não discutiremos aqui as moralidades pet e de parentesco porque sua lógica está baseada principalmente numa ordem de valores constitutivos da vida privada e o nosso foco aqui é o debate sobre a vida pública. É preciso argumentar ainda que não se trata exclusivamente de um desenho arbitrário, pois, a partir da experiência da observação participante, foi possível entender como a construção da moralidade da proteção se baseia numa rejeição da aproximação específica que caracteriza a experiência pet. A dimensão narcísica que caracteriza a intimidade burguesa (Sennett, 1988) é compreendida em termos morais pelos protetores como uma forma de coisificação dos animais, na qual os não humanos existiriam para gratificação dos seus “donos". Quando observamos o problema da relação com os animais em ambientes públicos, na rua, percebemos a constituição de justificações muito próximas de transações políticas que visam construir redes de influência e legitimidade com sentido cosmopolita.
} 
rua, bem como a morte de animais domiciliados que estivessem ou fossem suspeitos de estar infectados (Babboni \& Modolo, 2011; Belivacqua et al, 2000).

A epidemia de raiva no Brasil atingiu seu auge na segunda metade do século XX e, para combatê-la, foi criado, no final da década de 1970, o Programa Nacional de Profilaxia da Raiva (PNPR), que consistia em fornecer ou subsidiar soro e vacina antirrábica para pessoas mordidas, promover campanhas de vacinação para cães e, também, em tentar reduzir a população canina, a partir da eliminação de animais errantes (Teixeira, 1993; Souza, 2011). De forma não planejada, essas medidas reforçaram as representações sociais dos animais em situação de rua como doentes, sujos e agressivos. O medo de animais em situação de rua, portanto, não resultou diretamente das mortes ocasionadas por zoonoses, e sim da maneira como a população começou a ser alertada a respeito da doença e orientada pela mídia, por órgãos do Estado e por profissionais da saúde a evitar o contato com animais desconhecidos, vacinar os cães e gatos de casa e impedir que interagissem com os "de rua".

O crescimento do mercado pet e a entrada das mascotes dentro das casas estabeleceu uma dicotomia entre cães e gatos "especiais" e cães e gatos "sem importância". Além da raça, a utilidade e o vínculo afetivo com um humano poderiam estabelecer uma linha muito rígida entre animais a serem protegidos e animais a serem levados pela carrocinha. A persistente dicotomização e o fato de a carrocinha ter sido naturalizada por mais de três décadas tornaram improvável o surgimento de questionamentos morais sobre a captura e morte até o final da década de 1990.

Naquele final de século XX, já havia uma preocupação considerável em proteger a sensibilidade da população nas ações de captura e morte, decorrente da sensibilidade civilizada de condenação à violência. $\mathrm{O}$ regramento das ações de captura, transporte e eutanásia dos animais vedava o uso de técnicas utilizadas nas primeiras tentativas de controle populacional de cães e gatos, em que os animais eram capturados de forma agressiva e muitas vezes mortos a paulada ou envenenados no meio da rua (Aprobato Filho, 2007). Na Europa do início da Modernidade, que começava a se urbanizar, esse serviço não requeria treinamento e poderia ser realizado por qualquer pessoa, cujo pagamento comumente era calculado a partir do número de animais mortos (Babboni \& Modolo, 2011; Veloso, 2008). Desde a criação dos Centros de Controle de Zoonoses no Brasil, na década de 1970, o serviço de captura e morte de animais errantes foi atribuído a funcionários públicos, que deveriam ser treinados para realizá-lo de forma a garantir a 
própria segurança, a salubridade pública e a redução do sofrimento dos animais. Em consonância com essas exigências civilizatórias, as primeiras denúncias contra a carrocinha não questionavam a política de extermínio, e sim a captura de animais domiciliados e a brutalidade utilizada:

\begin{abstract}
Diante de tais ameaças, não se poderia contestar totalmente a validade da utilização da "carrocinha", em prol da saúde pública. O que se questiona, atualmente, é a forma como esse serviço vem atuando, principalmente quando se sabe que não são apenas os cães errantes os visados pelo Setor de Apreensão de Animais, conforme atestam depoimentos como estes (...) Muitas pessoas que já tiveram seus cães capturados pela "carrocinha" lamentam que não sejam poupados nem mesmo aqueles animais com coleira e que, portanto, têm dono (Cães \& Companhia, 1983a, n48: 11).
\end{abstract}

Feitas as ressalvas por procedimentos humanitários, o extermínio desses animais era legitimado fundamentalmente pela dicotomização em relação aos "especiais" e pela desindividualização conferida pelo distanciamento em que eram mantidos os animais "de rua", vistos como perigosos. Isso ocorria tanto pela ideia de que o extermínio fosse inevitável quanto pelo fato de que a sensibilidade moral hegemônica não identificava cães e gatos como sujeitos em uma relação moral, e sim como objetos.

As condições de naturalização e legitimação da violência, estabelecidas na sustentação dos serviços de controle de zoonoses, passaram a ser fragilizadas na configuração que se formou a partir dos anos 2000. Em certos aspectos, esse efeito foi gerado por ações planejadas pelos movimentos de proteção, mas, de maneira geral, essa figuração envolve um conjunto de elementos muito mais amplos que o ativismo e, na verdade, apresenta-se como condição na qual esse ativismo passou a crescer.

Em contraposição ao extermínio, alguns municípios e estados aprovaram leis que estabelecem a esterilização como único método aceitável para o controle populacional dessas espécies. As primeiras dessas mudanças legislativas ocorreram a partir dos anos 2000, partindo das cidades mais populosas e desenvolvidas, especialmente capitais como Rio de Janeiro (2004) e Curitiba (2005). Posteriormente, a captura e morte foi abolida nos estados de São Paulo (2008) Rio Grande do Sul (2009), Pernambuco (2010) e Rio de Janeiro (2013), cujas capitais são metrópoles com superpopulação de cães e gatos e, consequentemente enfrentam maiores dificuldades para realizarem a apreensão de animais errantes (gerando ainda menos eficácia no extermínio). A maioria dos movimentos de pressão para o estabelecimento de um novo modelo de relações entre 
humanos e não humanos surge nas grandes cidades. Nesse sentido, confirma-se o perfil que Elias $(1993,1994,1997,2011)$ identifica como protagonista dos impulsos civilizadores: uma parcela da população intelectualizada, de situação socioeconômica favorável e residente nos grandes centros urbanos.

Toda essa movimentação, ressalte-se, foi embasada pela publicação do relatório da OMS a respeito dos estudos de ecologia canina no controle da raiva, nos quais se concluiu que a captura e morte não é um método eficaz de controle populacional (Who, 1988, 1990). O oitavo relatório do Comitê de Especialistas em Raiva da OMS foi publicada no Brasil em 1992 e, a partir daí, os grupos de proteção animal ganharam um argumento técnico para se opor ao extermínio de animais recolhidos pelas chamadas carrocinhas. Embora a motivação dos militantes seja majoritariamente ética, todos os materiais produzidos, inclusive os projetos de lei, destacam o argumento técnico da eficácia na promoção da saúde pública, capaz de ganhar respaldo por parte de setores mais amplos da sociedade. Adicionalmente, passou-se a argumentar que as ações de extermínio por parte do Estado estimulavam a irresponsabilidade por parte dos tutores.

Hoje, o método de captura e morte continua sendo utilizado em muitas cidades, mas já não é alvo frequente de comentários jocosos sobre "cachorros que viram sabão" e a sua realização é cercada de protestos e denúncias. A imagem da carrocinha passou a ser associada à crueldade contra os animais, por isso a utilização dos veículos para ações de esterilização e adoção muitas vezes é vista com desconfiança.

Entre 2009 e 2013, cinco projetos de lei propuseram no Congresso Nacional a proibição da captura e morte de cães e gatos em situação de rua no Brasil ${ }^{6}$. Ainda que arquivadas ou deixadas de lado por vários anos, essas propostas indicam a formação de centros de pressão suficientes para gerarem uma demanda não apenas por normas municipais e estaduais, como também por uma legislação federal de proteção e defesa animal. A mudança para a qual o Estado brasileiro parece estar caminhando tem sido justificada, nas casas legislativas, com o argumento central da ineficácia técnica do extermínio (Lima \& Silva Netto, 2010). Alguns exemplos podem ser destacados entre os projetos de lei pioneiros de proibição da captura e morte de cães e gatos. Entre esses,

\footnotetext{
${ }^{6}$ Em 2003, foi proposto na Câmara dos Deputados o PL 1.376, o primeiro a visar ao estabelecimento da esterilização como única forma legítima de controle populacional de cães e gatos no Brasil. O projeto passou pela Câmara, foi enviado em dezembro de 2004 para o Senado e apenas em agosto de 2010 foi remetido de volta para a Câmara, com algumas emendas. Seis anos depois, o PL ainda não foi votado no plenário da Câmara dos Deputados. Entre 2009 e 2013, o Congresso Nacional recebeu outros cinco PL sobre controle populacional de cães e gatos, mas todos foram reunidos (apensados) ao projeto de criação do Código Federal de Bem-Estar Animal (PL 215/2007), parado até o presente momento.
} 
o PL 117/2008, de São Paulo, ressalta os interesses em comum entre a proteção dos animais e a proteção da salubridade pública:

Da ultrapassada política de saúde decorre o crescente número de cães e gatos que pelas ruas vagam (...)Convém lembrar que a proteção aos animais e a salubridade pública, longe de serem valores antagônicos ou irreconciliáveis, são interesses que se vinculam e que se voltam a um mesmo fim, já que as medidas que protegem os animais são as mesmas preconizadas pela OMS, por atuarem na defesa da incolumidade pública (São Paulo, PL 117/08).

Já o PL 1703/2003, do Rio de Janeiro, refere-se à captura e morte de animais errantes como "prática antiética, tecnicamente obsoleta, ineficaz e dispendiosa, atentando contra os princípios da moralidade e da eficiência”. Por fim, o PL 1376/2003, de caráter nacional, caracteriza a mudança na política de controle populacional como forma de atender às normas de saúde, prevenir crimes ambientais e prezar pela moralidade e pela eficiência na administração pública:

E não cabe à saúde pública atuar com critério leigo, se há critério técnico solucionando o problema. Não enfrentar a questão é desatender às normas de saúde pública, mesmo porque, o aumento do número de animais de rua, não vacinados e não assistidos, é fator facilitador da disseminação de doenças.

O povo deve ser conscientizado da necessidade de esterilizar os animais, ainda que domiciliados, para que se ponha fim à cruel e criminosa prática do abandono de filhotes indesejados, que contribui para o aumento de animais de rua e a sua conseqüente exposição a maus-tratos, além de incidir na norma punitiva do artigo 32 da Lei $\mathrm{n}^{\circ} 9.605 / 98(\ldots)$

O método atualmente empregado, além de ser oneroso para os cofres públicos, carece de ética e de eficácia, o que atenta contra os princípios da moralidade e da eficiência (Brasil, PL 1376/2003).

Apesar das iniciativas legislativas para substituir a eutanásia de animais saudáveis pela esterilização cirúrgica, o Ministério da Saúde ainda preconiza o procedimento tradicional de captura e morte de $20 \%$ da população canina a cada ano, de acordo com o Guia de Vigilância Epidemiológica. No mesmo documento, são previstas medidas educativas de combate à raiva e, entre elas, encontra-se a orientação seguinte:

Não valorizar a proteção do cão errante, mostrando o potencial zoonótico como reservatório de doenças desses animais, assim como o incômodo e agressões que os mesmos podem ocasionar (Brasil, 2009: 30). 
Ao apontar a proteção aos cães errantes como empecilho, o documento evidencia a exclusão desses animais do leque de preocupações morais dos formuladores das políticas de saúde. Nesse sentido, é importante retomar a observação de Osório (2013), de que, diferente das iniciativas de caráter higienizante e modernizador que marcaram o século XIX, as tentativas atuais de retirar os animais do espaço público são motivadas pela lógica de proteção aos animais. Embora concordemos com essa abordagem, consideramos importante destacar que, ao longo do século XX, essas políticas foram fundamentadas por um discurso sanitarista, que permanece central no presente, mesclado aos discursos da proteção. Diante desse quadro, uma reflexão sobre a relação entre civilidade e empatia pode contribuir para que se entenda a emergência de sensibilidades e valores distintos nesse processo, bem como as relações ambíguas entre diferentes ordenamentos morais nos debates sobre o manejo de cães e gatos.

\section{Proteção Animal em Recife: a trajetória de um problema moral}

Os grupos de proteção animal mais antigos na Região Metropolitana do Recife são a Sociedade de Proteção aos Animais (que, segundo relatos, foi criada na década de 1990) e a Associação Amigos Defensores dos Animais e do Meio Ambiente (Aadama), fundada no início dos anos 2000 (segundo ata de fundação, disponível no site do grupo). Outros grupos surgiram, em meados dos anos 2000, como a Brazucas Associação para Lutar pelos Animais (Brala), o Movimento de Proteção Cães da Colina (MPC), o Serviço de Auxílio à Vida Animal e ao Meio Ambiente (Savama), a Arca de Noé e o Projeto de Extensão Adote um Vira-Lata, da UFPE. Do momento da fundação até o início dos anos 2010, cada um desses grupos atuou de forma relativamente isolada e com ações de caráter assistencialista, a maioria com foco no resgate de animais, busca de adoção, criação de abrigos de animais ou auxílio a abrigos já existentes.

Quatro fatores dificultavam a pressão política por parte da proteção animal na Região Metropolitana do Recife: 1 - Não havia ainda reconhecimento social em relação ao problema dos animais de estimação como questão pública - o que incluía falta de atenção por parte da mídia; 2 - embora já houvesse grupos em diálogo com políticos, esses encontros não eram a atividade central e essas primeiras ações de mobilização política não eram divulgadas, o que dificultava a agregação de um número maior de entidades e formação de atos ampliados de apoio; 3 - os grupos de proteção animal 
eram pouco conhecidos e o ganho de visibilidade era dificultado pela inexperiência na realização e divulgação de eventos, campanhas e mobilizações de rua; 4 - o uso de email e da rede social Orkut não tinha a capacidade de difusão que mais tarde seria possibilitada pelo Facebook. O site Rede de Adoção, principal instrumento utilizado pelos protetores, também tinha um público relativamente restrito.

Diante dessas limitações, os três projetos de lei propostos nesse período foram descartados sem muita repercussão. Em 2006, o PL 83 propôs a proibição da circulação de veículos de tração animal em Recife, mas foi retirado da pauta e arquivado pelo próprio autor; em 2008, o PL 66 propôs mudança na política de controle populacional de cães e gatos, mas foi vetado totalmente, pelo então prefeito, com o argumento de inconstitucionalidade; no ano seguinte, o PL50/2009 propôs a implantação de um centro de esterilização de animais, mas foi rejeitado na Câmara dos Vereadores.

Foi apenas no final de 2008 que a pressão política pela atenção do Estado aos animais não humanos começou a ganhar vulto na Região Metropolitana do Recife, com a criação do movimento Recife Contra a Carrocinha, promovido pelo grupo Ativistas pelos Direitos dos Animais (ADA), formado por estudantes da UFPE. As estratégias utilizadas pelo movimento foram criação de blog e site, petição virtual, venda de camisetas com os dizeres "Eu sou contra a carrocinha" e uma manifestação em frente à Prefeitura da Cidade do Recife. A campanha "Recife Contra a Carrocinha" colocou em pauta o debate sobre a política de controle de zoonoses, que, até aquele momento, consistia na captura e morte de cães e gatos em situação de rua.

O desenvolvimento dessa preocupação moral com uma situação que não estava diretamente visível foi estimulado pelo movimento. Na postagem inaugural do blog, que convocava a população a se mobilizar, foi feita uma descrição de como funcionava a carrocinha, descortinando os procedimentos realizados longe dos olhos, apelando para a sensibilidade civilizada de condenação à violência. Em seguida, a normalidade da técnica era questionada com uma referência à nova diretriz da OMS, oferecendo o respaldo técnico à demanda, defendida pelo movimento, de substituição do método por “controle da natalidade através da esterilização, campanha de conscientização para a guarda responsável dos animais e outras medidas”. Ressaltando a ambiguidade das relações travadas com cães e gatos em Recife, o texto era encerrado com a afirmação da senciência das vítimas, estabelecendo uma conexão entre os animais anônimos, mortos no CVA, e aqueles com os quais o público potencialmente estabelecia relações afetivas: 
Centenas de cães e gatos, doentes ou não, são mortos toda semana no Centro de Vigilância Ambiental de Recife. Centenas de animais sencientes (sensíveis à dor e ao sofrimento), inocentes e, ainda, chamados "os melhores amigos do homem". Nenhuma diferença existe entre o cão, de rua e sem raça definida, que é executado no CVA, e o amado e bem cuidado cão de estimação seu ou da sua prima.

Aquele cachorro ou gato que você vê todo dia na sua calçada, no caminho ao trabalho ou no seu local de estudo; aquele cachorro ou gato que vem brincar com você e que vem lhe pedir comida ou apenas um pouco de carinho; aquele animal, ser vivo senciente e emotivo como você, que percebe e sofre o frio, a dor e a fome como você. Aquele cão, meus caros, livre e feliz, que mora em Casa Amarela, em Boa Viagem, no Engenho do Meio ou no Ibura... Esse animal pode ser capturado, maltratado e executado ainda essa semana. E continuará a poder sofrer tais abusos enquanto persistir o sistema da nossa perversa Carrocinha.

Não há argumentos que sustentem a existência da Carrocinha, a não ser a ignorância, o tradicionalismo e a indiferença dos nossos governantes. Junte-se a nós nessa luta.Mobilizemos o Recife contra a Carrocinha.(ADA- Ativistas pelos Direitos dos Animais, 2010, grifo nosso)

É perceptível, neste texto, o apelo à sensibilidade civilizada que impôs procedimentos humanitários e, de forma não planejada, estimulou o questionamento à própria necessidade da morte e à possibilidade de haver extermínio, de fato, humanitário. Diante dessas indicações, parece claro que o aumento dos patamares da sensibilidade civilizada compõe a figuração em que se torna possível a emergência de questionamentos voltados não apenas à proteção da sensibilidade humana, mas também a uma percepção dos cães e gatos como seres moralmente relevantes. A sensibilidade civilizada, portanto, joga um papel fundamental no processo em curso, pois faz parte da construção e da expansão da sensibilidade de empatia interespécie.

O protesto organizado pelo movimento ocorreu em 10 de dezembro de 2008, em uma praça próxima à sede da Prefeitura do Recife. Em termos quantitativos, o "Recife Contra a Carrocinha" não foi tão expressivo (segundo relatos, reuniu cerca de 150 pessoas), mas sua realização teve um peso considerável para os grupos de proteção e defesa animal, que tiveram ali uma oportunidade de travar contatos e atuar em conjunto, além de mobilizar a mídia, que aos poucos começou a veicular notas e cartas de leitores sobre a carrocinha e sobre a esterilização de cães e gatos.

A relevância da cobertura midiática na consolidação de um novo problema ambiental ou social é visível no caso de Pernambuco. A atenção da mídia pernambucana para a causa animal começou a ocorrer em 2009 e se tornou mais expressiva a partir de 2010, com a veiculação de notícias e reportagens nacionais sobre resgates, abrigos e eventos de adoção. Essa atenção da mídia evidencia uma mudança de sensibilidade, que passa a posicionar gatos e cães como relevantes, interessantes e necessitados da 
solidariedade e/ou da responsabilidade humana. Ao mesmo tempo, por alcançarem um público amplo e diverso, esses veículos de comunicação funcionam como importantes estímulos para a difusão da sensibilidade de empatia interespécie.

A campanha pelo fim da carrocinha em Pernambuco foi um importante estímulo para o crescimento da proteção animal. Em levantamento realizado em 2011, 13 grupos organizados de proteção animal foram identificados em Pernambuco (Braga et al, 2011). Em um novo levantamento, no ano de 2015, alguns daqueles grupos haviam desaparecido, enquanto vários outros surgiram, formando um total de 23 grupos que atuavam de formas variadas, entre as quais destacam-se: promoção de eventos de adoção, manutenção ou auxílio a abrigos ou colônias, organização de mutirões de castração, campanhas educativas sobre guarda responsável ${ }^{7}$. Foram identificadas também três comunidades virtuais de proteção animal no Facebook e três grupos de ativismo vegano (Lima, 2016). O crescimento dos grupos de proteção é relevante porque os sujeitos envolvidos nesse tipo de ativismo passaram a assumir um papel ativo tanto na resolução de problemas antes abordados pelo extermínio quanto na denúncia das tentativas privadas de resolução via envenenamento e ameaças aos animais e aos protetores que os alimentam, especialmente no caso das colônias.

\section{A sensibilidade civilizada diante dos animais no espaço público}

A busca pela eficiência e pela proteção à sensibilidade civilizada tem sido preponderante na decisão de trocar a política de captura e morte de animais errantes por uma política de esterilização de cães e gatos. Essa mudança, porém, exige a implementação de um programa intensivo de castração em massa para que a superpopulação de animais em situação de rua seja reduzida e, em Pernambuco, não existe atualmente nenhuma iniciativa nesse sentido. De maneira imediata, portanto, a proibição do extermínio de animais em situação de rua aumentou os conflitos relacionados à presença de animais no espaço público, pois a solução tradicional de

\footnotetext{
${ }^{7}$ Os grupos de proteção animal identificados foram: Associação dos Protetores de Animais de Aldeia (AAPA), Associação de Proteção aos Animais (APA), Adote um Bichano (AUB), Associação dos Amigos Defensores dos Animais e do Meio Ambiente (AADAMA), Associação de Defesa do Meio Ambiente (Ademape) Adote um Vira-Lata (UFPE), Bicharada Carente, Brazucas Associação para Lutar pelos Animais (Brala), Eu Amo Animais, Gatinhos Urbanos, Gigi Pet Sitter, Julietas, Movimento Ação Animal (MAA), Movimento Amigo Bicho (MAB), Movimento de Defesa Animal (MDA), Movimento de Proteção Cães da Colina (MPC), Pet PE, Projeto Animus (UFRPE), Projeto Patinhas, Savama, SOS 4 Patas, SOS Vida e a ONG Centro de Controle de Natalidade Animal (CCNA).
} 
chamar a carrocinha, embora ineficaz como forma de controle populacional, tinha o efeito visual higienizante de remover o problema de determinado local, ao menos por algumas semanas. Ao repudiar os paliativos higienizantes, a sensibilidade de empatia entra em choque com a moralidade civilizada, com seu estilo "don't ask, don't tell" no trato do sofrimento de animais não humanos. A implementação de políticas baseadas na empatia implicaria em lidar com os animais errantes, ao invés de simplesmente retirálos da vista. Por mais que a proibição do extermínio seja um passo nessa direção, o cenário real das grandes cidades brasileiras não é de mudança de uma moralidade a outra, e sim de tensões geradas por uma mudança normativa que entra em choque com a moralidade civilizada, que continua sendo o padrão.

Desde que a "Lei da Vida" (14.139/2010) foi aprovada em Pernambuco, os Centros de Vigilância Ambiental (CVA) deixaram de atender aos pedidos de recolhimento de animais, atendo-se apenas aos agressivos ou com potencial zoonótico. O conflito de atribuições do Centro aumentou em 2013, com a criação da Secretaria Executiva de Direito dos Animais (SEDA) na Prefeitura do Recife. Essa pasta seria responsável pela promoção de bem-estar e controle populacional, mas não recebeu estrutura física própria e não estabeleceu um programa consistente de controle populacional, tornando-se alvo permanente de denúncias por parte da proteção animal ${ }^{8}$.

Esse problema político é relevante para a compreensão de como foram se constituindo os posicionamentos no debate sobre o lugar dos animais não humanos na vida pública. Ao mesmo tempo em que legitimou a atenção para os animais por parte do Estado, a inserção dos animais não humanos na agenda política e a criação da SEDA e geraram dois efeitos não planejados: o primeiro foi o aumento das exigências por parte da população, que passou a cobrar do Estado (especialmente da Prefeitura do Recife) o recolhimento, castração, tratamento e adoção de animais em situação de rua (especialmente de colônias que estejam causando incômodo). Dada a incapacidade institucional de resolver os numerosos casos pontuais (agravada pela ausência de uma política de controle populacional), o segundo efeito foi o aumento dos conflitos entre indivíduos que convivem com os animais errantes. É nesse sentido que podemos perceber que a sensibilidade de empatia tem ganhado espaço timidamente e está longe de se impor como principal ordenador das ações relativas aos animais não humanos no

\footnotetext{
${ }^{8}$ Esse conflito pode ser percebido na mídia local, que noticiou protestos e denúncias contra a SEDA em todos os anos da gestão (Albuquerque, 2013, Blog do Jamildo, 2013; Braga; 2014; Brito, 2013; Brito, 2014; Diário de Pernambuco, 2015; Leia Já, 2015).
} 
espaço público. Apesar do evidente "déficit moral" da perspectiva civilizada, presa a uma sensibilidade antropocêntrica, é justamente a moralidade civilizada, com a preocupação de proteger a sensibilidade humana, que se apresenta hoje como fundamento normativo central do tratamento de espécies não humanas. Assim, a abolição do extermínio trouxe à tona o incômodo gerado pela presença de animais no espaço público, especialmente no caso das colônias de gatos, presentes em diversas praças, parques, mercados e campus universitários da Região Metropolitana do Recife. Também aqui opera o "processo de retroalimentação dos espaços do abandono" identificado por Osório (2013), segundo a qual "a existência de colônias constituídas e de protetores vinculados a elas cria novos abandonos no mesmo local porque suscitam a percepção de que ali o animal estará sendo cuidado, alimentado e, portanto, não está sendo abandonado" (idem, ibidem: 159).

A capacidade que esses animais (especialmente os gatos) têm de mobilizar emoções díspares fica evidente quando a sua morte é intencionalmente provocada ou defendida publicamente. Um caso rico para ilustrar essa situação ocorreu em 2012, quando o cientista político Daniel Menezes publicou um artigo opinativo intitulado "Morte aos gatos", em que cobrava do poder público mais eficácia na captura e eliminação de felinos em Natal, especialmente no campus da UFRN, pois, de acordo com ele, a cidade passava por um grande surto de toxoplasmose, resultante do contato com os gatos. O texto foi introduzido com um ataque à "inversão de valores" representada pela condenação à política de captura e morte desses animais:

O que pensar de uma relação em que uma pessoa deixa de se importar com outro indivíduo para se autoafagar como benfeitora porque alimentou um cachorro de rua? Como conceber que, enquanto países como França, EUA, Inglaterra etc., fazem controle da população de animais - sim, o excesso é sacrificado -, nós, em Natal, estamos sofrendo - pela suposta bondade de alguns - com o aumento do número de infectados com a chamada 'doença do gato', a toxoplasmose? O que tornou possível a inversão de valores? Em que o paradeiro de um bicho se torna mais importante do que o sofrimento de um ser humano? (Menezes, 2012a).

A solução cobrada (morte aos gatos) foi justificada com uma reafirmação do ordenamento moral em que humanos são inquestionavelmente superiores a cães e gatos. Além disso, a imagem de animais em situação e rua como perigosos era reforçada com a afirmação de que o ato de os alimentar deveria ser criminalizado por constituir-se em 
uma ameaça à vida das pessoas, sendo então cabível perguntar: "que a gente prefere um gato vivo a nosso irmão, amigo, filho ou colega hospitalizado" (Menezes, 2012a).

Em poucos dias, centenas de comentários foram deixados no site, em uma polêmica acirrada a respeito do tema. Baseado em um ordenamento moral no qual os animais não humanos não são relevantes, o autor do artigo "Morte aos gatos" despertou a fúria de internautas de diferentes estados do país, que deslegitimavam sua reivindicação como cruel, injusta e desinformada. As respostas dos defensores dos gatos variavam de esclarecimentos sobre zoonoses a xingamentos pessoais ao autor do artigo. Entre as repercussões do texto, pode-se destacar um artigo de resposta, publicado na Agência de Notícias de Direitos Animais, em que o ativista vegano Robson de Souza acusou Menezes de incitar violência contra os felinos a partir de uma falsa dicotomia entre defender a vida dos humanos e a vida dos gatos. Como é recorrente nos debates sobre felinos, Souza afirmou que Menezes agiu de forma intelectualmente desonesta, por fornecer informações incorretas sobre a transmissão da toxoplasmose e sobre os métodos eficazes de controle populacional. Ao concluir o artigo, recorreu ao paralelo entre o extermínio de animais e o holocausto, perguntando por que as pessoas prefeririam ser "politicamente incorretas" a ser "respeitosas, empáticas e intelectualmente honestas" (Souza, 2012a).

Além de diferentes ordenamentos morais, Souza (2012a, 2012b) e Menezes (2012a, 2012b) apresentavam diferentes interpretações sobre o que seria uma relação civilizada com os animais. Por um lado, Menezes falava em civilidade como uso racional e humanitário dos "animais não racionais", apontando como exemplos seu uso para alimentação, pesquisas e testes farmacológicos, bem como a captura e morte de animais em situação de rua. Por outro lado, Souza apresentava civilidade como capacidade de debater e buscar soluções sem agressividade, seja contra humanos, seja contra outros animais. Dando continuidade à polêmica, tanto Menezes quanto Souza publicaram novo artigo, reforçando argumentos e procurando rebater as questões levantadas pelo outro. Esse caso é interessante porque representa bem os debates que a primeira autora acompanhou em sua pesquisa de campo, tanto em relação aos campus da UFPE e da UFRPE quanto em relação às colônias de gatos na Região Metropolitana do Recife. Em vários momentos, a morte dos gatos é defendida explicitamente e justificada em termos sanitários, como prevenção à toxoplasmose e/ou à manutenção da 
higiene do local ${ }^{9}$. Em defesa dos animais, os grupos organizados costumam usar o argumento da eficácia, enquanto os simpatizantes da causa e os protetores independentes usam mais comumente o argumento do direito à vida. Quando a solicitação é a retirada dos animais, o debate passa a ser a respeito do que ocorrerá em seguida, pois, nesse caso, a preocupação passa a ser com o bem-estar dos animais recolhidos e com o ressurgimento da colônia a partir dos novos abandonos no local.

O cenário aqui analisado, de acirramento dos conflitos sobre as possibilidades de interação entre humanos e não humanos no espaço público, desenvolve-se com frequência quando os argumentos baseados em moralidades de caráter antropocêntrico (que limitam a comunidade moral aos humanos) entram em disputa com os valores da moralidade de proteção (que inclui cães e gatos na comunidade moral e atribui aos humanos a responsabilidade de zelar por eles). Para além do caso apresentado, esses dois modos representam duas maneiras radicalmente distintas de realizar julgamentos morais e de fundamentar as ações na relação com animais não humanos. Entre os contrastes já identificados, cabe destacar a disparidade nas representações a respeito do risco de adoecimento e, paralelamente, nas emoções de nojo e medo diante dos animais.

\section{Medo e nojo: civilidade e dores emocionais}

O medo de adoecimento pelo contato com os animais é perceptível em todas as classes sociais e não se limita às zoonoses propriamente ditas, pois cães e gatos são comumente relacionados a doenças que não são sequer capazes de contrair ou transmitir para humanos. Em blogs que oferecem orientações para os tutores (assumindo a função de manuais de guarda responsável), comentários feitos por internautas demonstram a extensão do pânico de contrair doenças pelo contato com esses animais ${ }^{10}$ :

\footnotetext{
${ }^{9}$ Por outro lado, em consonância com a conclusão de Osório (2011) sobre sacralização dos cães, o desejo de eliminação em massa da espécie canina, mesmo que exista, não chega a ser defendido abertamente. ${ }^{10}$ Os comentários foram feitos em publicações sobre zoonoses nos sites Terra.com.br, Maisequilibrio.com.br, saudeinfantil.blog.br e brupacifico.com.br. Para preservar a identidade dos internautas, optamos por não divulgar o endereço completo das matérias nem identificar em qual delas foi feito cada comentário. Para facilitar a compreensão, os comentários passaram por revisão ortográfica.
} 
A. P. (mulher) - Obrigada, foi muito instrutivo. Mas na verdade vim à procura de tirar uma dúvida, pois uma amiga está com Leucemia e disseram que isso aconteceu depois de uma mordida de gato, estranhei, então fui tirar a dúvida. pelo que li entendi que o gato contamina o ser humano de muitas outras formas, menos por leucemia. Valeu!

E.S. (homem) - (...) até a hora que vc ou alguém pegar uma doença. Aí você vai falar: "Ai, cuido tão bem deles, jamais pensei que iria acontecer comigo". Acorda mocinha, já peguei gonorreia de gata

D. (mulher) - Boa noite! Se um cão morder uma pessoa com aids, o cão se contamina com aids também? Não se contamina e o vírus morre? Ou ainda, o cão não desenvolve a doença, mas o vírus fica vivo dentro do cão?

F.S. (homem) - Gostaria de saber sobre uma doença que leva ao desmaio, me falaram que era o bicho do cachorro no cérebro, e meu filho está com isso, gostaria de informação, ele desmaia toda hora...

J. (mulher) - tenho um gato, minha filha está constantemente enjoada, vomitando, dor de cabeça e, segundo o médico, com fígado e baço alterados. Um amigo me disse que talvez seja causado pelo pelos do gato.

Ao longo do período de observação participante em eventos de adoção e netnografia no Facebook, esse temor foi expresso diversas vezes, em geral acompanhado por caretas de nojo, contenção das crianças, para que não tocassem nos animais, e busca de local para lavar as mãos. A preocupação era recorrente tanto entre pessoas que tinham a primeira experiência de criar animais quanto entre as que estavam começando a conhecer a proteção animal e questionavam, preocupadas, se os protetores não tinham medo de "pegar alguma coisa" ou como seria possível saber que os animais não estavam doentes ou não seriam agressivos. Diante da persistência das representações da animalidade como perigo e das emoções negativas relacionadas (medo e nojo), as propostas de solução baseadas nas moralidades antropocêntricas entram em choque com a perspectiva das moralidades fundadas na sensibilidade de empatia interespécie.

A autojustificação da moralidade civilizada está baseada na ideia de respeito aos animais e da necessidade de evitar seu sofrimento como uma extensão necessária do autorrespeito humano (Serpell \& Paul, 2003). Poderíamos discutir longamente sobre as implicações éticas de que o tratamento de outros seres esteja submetido à necessidade de proteção das sensibilidades e interesses humanos. Aqui, no entanto, é mais importante perceber que, historicamente, tais ideias de respeito estiveram também em estreita conexão com a necessidade de afastamento e desconfiança em relação à 
animalidade e às suas características. Se o processo civilizador representa a tentativa de controle de nossa natureza animal, podemos muito bem entender que a "animalidade dos animais" representa uma situação limiar, uma ameaça ou lembrança do que deve ser controlado. Desse modo, na relação com as outras espécies, temos uma organização sensível em que os ideais de respeito foram salvaguardados e constituídos através da ordenação do nojo e do medo como emoções fundamentais. Ainda que as explicações sobre o nojo assumam um tom quase naturalista, como se se tratasse de uma aversão produzida com fins de proteção do organismo, Norbert Elias (2011) demonstrou seu caráter de emoção não natural ao apresentar como, na Idade Média, havia níveis muito mais altos de tolerância a secreções, odores e sons produzidos pelo corpo. Interessa aqui perceber dois aspectos: 1- a diminuição dessa tolerância, associada a formas de autocontrole, é fruto de disputas por distinção e superioridade moral; 2 - a internalização dessas ordens de controle da experiência são tão bem sucedidas quanto conseguem mimetizar imperativos construídos socialmente como impulsos naturais. Para a presente discussão, enfatizamos que o nojo sentido diante dos animais não humanos, assim como o medo, não é natural nem imediato ${ }^{11}$. Dito de modo simples: as emoções e reações humanas diante de outros animais está sujeita a uma ampla variedade de modulações historicamente determinadas. E nesse sentido, a perspectiva eliasiana do processo civilizador nos ajuda a perceber como os padrões de controle do corpo entre humanos projeta ordens sobre os não humanos.

Distinguir claramente entre os sentimentos de nojo e medo nas interações analisadas é uma tarefa difícil. Encontramos uma constante sobreposição de tais sentidos, de modo a percebermos que se reforçam e contrabalanceiam como meios de construção de uma relação segura e civilizada. De fato, a identificação em separado dessas emoções experienciadas em tal figuração particular não faz sentido diante da perspectiva teórica aqui trabalhada. Se observarmos o desenvolvimento da teoria eliasiana, percebemos a tentativa de estabelecer, num diálogo direto com Freud, o processo civilizador como a forma histórica de transmissão e internalização do tabu da vergonha. Contudo, apesar da centralidade da vergonha como elemento de repressão na história europeia, Scheff (2004) chama atenção para o fato de que, nesse diálogo entre

\footnotetext{
${ }^{11} \mathrm{O}$ caráter social do nojo pode ser percebido no contraste entre as reações atuais às fezes de equinos e a postura de um médico que, em 1705, afirmou que as fezes desses animais tinham bom cheiro porque o Criador sabia que eles estariam sempre perto dos homens (Thomas, 2010: 24).
} 
Freud e Elias, o que está em jogo não é a vergonha - emoção particular, mas um conjunto amplo de "dores emocionais". Nesse sentido, também temos em associação com a vergonha o medo, o nojo, o embaraço e culpa. Trata-se, então, de um conjunto de emoções dolorosas, que são parte dos mecanismos de repressão e internalização de uma ordem da contenção e do recato que, uma vez mobilizadas em redes de interdependência, desenvolvem-se como parte de um processo amplo, que tensiona autocontrole e controle social. Assim, nas interações com cães e gatos, medo e nojo se complementam e mais importante que isolá-las na experiência é compreender como elas operam para criar regras definidoras dos limites entre as espécies.

Seja no caso da proteção ou do público, não estamos diante de um debate com deduções lógicas, mas de um processo de justificação moral que tem suas bases na manipulação das sensações e no ordenamento das emoções dadas no encontro entre humanos e não humanos. Por fim, precisamos também indicar que essa perspectiva aberta por Scheff, de pensar não em emoções específicas, mas no conjunto de dores emocionais resultantes das formas de controle e repressão, abre o caminho para um uso mais frutífero da teoria do processo civilizador e de sua aplicação a situações distintas do desenvolvimento europeu, como buscamos realizar aqui. Contextos históricos particulares podem apresentar ênfases em emoções distintas, mas o que seria característico do processo civilizador é a ordenação de dores emocionais na produção de redes de controle social vis-à-vis formas de autocontrole sistemático.

\section{Medo persistente: cães e gatos como fonte de risco}

O medo é uma característica cultural que compõe as ambiguidades das relações com cães e gatos no Brasil e, como se pode perceber nos comentários de internautas listados acima, não é preciso que haja um risco objetivamente mensurável para que essa emoção se perpetue. Um exemplo importante de como essa emoção está presente na Região Metropolitana do Recife é a persistência de um forte temor em relação à raiva, a despeito da significativa redução da incidência dessa zoonose no Brasil.

Estimativas de 2001 sugerem que o número de mortes pela raiva em todo o mundo pode variar de 40.000 a mais de 70.000 por ano, com forte concentração no continente asiático (de 35.000 a 55.000 casos humanos por ano e aproximadamente sete milhões de pessoas recebendo tratamento antirrábico com vacina). O continente 
africano é o segundo com maior número de casos humanos de raiva (de 5.000 a 15.000 mortes por ano e cerca de 500.000 pessoas vacinadas contra a doença). Em comparação a esses continentes, a América Latina tem atualmente um número bastante reduzido de casos (menos de 100 por ano e média de 500.000 recebendo tratamento pós-exposição, todos os anos). Por fim, os menores índices estão na América do Norte e na Europa, com menos de 50 casos humanos e cerca de 100.000 pessoas submetidas a tratamento antirrábico a cada ano (Belotto apud Cortez, 2006) ${ }^{12}$.

Similarmente ao que ocorreu nos demais países americanos e na Europa e, a incidência de raiva no Brasil diminuiu substancialmente a partir da instituição do Programa Nacional de Profilaxia da Raiva (PNPR), com a realização de 350.000 tratamentos pós-exposição e cerca de 9.000 .000 vacinas aplicadas em cães e gatos a cada ano. Como resultado, entre as décadas de 1980 e 1990, houve no Brasil uma redução de $78 \%$ nos casos humanos e $90 \%$ nos casos caninos de raiva (Cortez, 2006). O programa começou em 1973, atuando nas zonas urbanas das capitais e regiões metropolitanas, onde estava concentrada a maioria dos agravos e, até 1977, estendeu-se às cidades do interior e à zona rural.

Passados 40 anos desde a criação do PNPR, os casos de raiva atualmente estão concentrados na zona rural e a espécie canina, que até 2001 estava envolvida em 70 ou $80 \%$ dos casos humanos, foi em vários anos superada pela transmissão por morcegos hematófagos, mais comuns no meio rural. Também surgiu uma preocupação com outras espécies da fauna silvestre, como saguis e raposas (Babboni \& Modolo, 2011; Gomes, 2004). Nos dados mais recentes, Penna (2010) destaca não apenas a queda na incidência, como também a mudança no perfil dos animais envolvidos nos casos de raiva humana. Após um período de grande queda entre as décadas de 1970 e 1990, a incidência de raiva no Brasil alcançou uma estabilidade a partir do ano de 1994, com os casos concentrados nas regiões Norte e Nordeste. Entre janeiro de 1992 e dezembro de 2001, foram notificados 313 casos de raiva humana no país, sendo 28 no estado de Pernambuco, com uma média de 2,8 casos ao ano (Gomes, 2004: 30). Atualmente, Pernambuco é o $2^{\circ}$ estado mais atingido pela doença no Brasil, tendo apresentado 40 casos entre os anos de 2007 e 2010, em 22 municípios distintos (Brasil, 2011: 20).

\footnotetext{
${ }^{12}$ A discrepância entre os continentes é especialmente relevante quando se considera que na Ásia e na África ocorre extermínio sistemático de animais em situação de rua. A diferença entre esses locais e os continentes Europeu e Americano é a vacinação dos cães e gatos, que exige um investimento inicial alto.
} 
Embora a totalidade dos casos atualmente seja pequena e esteja concentrada nas zonas rurais, o medo em relação às mordeduras continua forte na Região Metropolitana do Recife, inclusive quando envolvem animais vacinados ${ }^{13}$. Além disso, é possível constatar a persistência da associação entre os animais em situação de rua e a raiva, tanto nas falas cotidianas quanto na mídia. No ano de 2012, por exemplo, uma reportagem televisiva sobre a raiva, veiculada em um dos jornais locais, estimulava todas as pessoas mordidas ou arranhadas por cães, gatos ou animais silvestres a procurarem o tratamento antirrábico. Para anunciar a matéria, o jornalista que apresentava o programa leu o seguinte texto de introdução:

É muito comum encontrar cachorros soltos pelas ruas e avenidas da Região Metropolitana. Animais que, quase sempre, estão doentes ou famintos. Alguns são mais agressivos, chegam a atacar e morder as pessoas. De janeiro a julho desse ano, de acordo com a Secretaria de Saúde do Recife, mais de 2.500 pessoas foram mordidas na cidade. No ano passado foram quase 4.000 ataques. Quando isso acontece, você sabe o que fazer?

Ao associar animais em situação de rua a mordeduras e caracterizá-las como ataques de animais agressivos e famintos, a peça jornalística demonstra a persistência do pânico que caracterizou as décadas de 1970 a 1990. Certamente as matérias desse tipo já não são recorrentes e tornou-se comum apresentar campanhas de vacinação antirrábica como ação para o bem dos próprios animais, mas esse é um processo com muitas descontinuidades. É assim que as campanhas de vacinação em diferentes municípios alternam o discurso da vacina como proteção para as pessoas e como proteção para os animais, algumas vezes apresentados como membros da família.

Além da raiva, um exemplo importante do pânico das zoonoses é a toxoplasmose, popularmente conhecida como "doença do gato" e representada como um perigo constante, alojado nos felinos, à espreita de uma grávida ou de uma criança para contaminar ${ }^{14}$. As pesquisas com o protozoário apontam que um gato infectado libera oocistos por um período médio de uma semana e que a transmissão não se dá pelo contato com o corpo ou o ambiente dos animais infectados, e sim pela ingestão de água não tratada, carne mal passada, verduras mal higienizadas ou, com menor probabilidade,

\footnotetext{
${ }^{13}$ É cabível citar que, nos levantamentos sobre mordeduras, uma parcela expressiva dos casos acontece dentro de casa, com animais conhecidos.

${ }^{14}$ Embora o protozoário toxoplasma gondii seja encontrável em qualquer espécie de ave ou mamífero, é ao passar pelo trato intestinal de um felino e ser liberado nas fezes que o parasito adquire a forma infectante, responsável pela contaminação do solo da água e, consequentemente, de plantas e animais.
} 
pelo ato de levar a mão à boca após o manuseio de solo contaminado (CRMV-PR, CRMV-SC, CRMV-RS, 2010; Elmore et al, 210; Lima \& Luna, 2012; Maciel, 2004; Monteiro et al, 2012; Schnell, 2012, Silva, 2008).

Entretanto, contrariamente às indicações científicas, as representações sociais sobre a toxoplasmose apontam o contato direto ou indireto com o corpo de um gato contaminado como a principal (quando não a única) fonte de infecção (Silveira, 2015). O desconhecimento sobre a transmissão da doença é cercado pela difusão de ideias fantasiosas sobre transmissão por vias aéreas ou pelo toque, de forma que o resultado é a repulsa e a evitação do contato com gatos. No meio urbano, esse pânico também é perceptível em relação aos pombos, que embora possam transmitir zoonoses, são entendidos como fonte de doenças que não transmitem pelo contato ou pelas fezes, como a toxoplasmose, ou de doenças que não existem no Brasil, como a influenza aviária (Miranda, Ladendorff \& Knöbi, 2014). No caso dos felinos, a representação de perigo é reproduzida inclusive por profissionais da medicina, como indicam estudos sobre recomendações médicas, para gestantes, a respeito de toxoplasmose (Carellos, Andrade \& Aguiar, 2008; Jones et al, 2001) ${ }^{15}$.

As representações a respeito da toxoplasmose geram imagens de um risco disperso por todo o ambiente em que existam gatos, inclusive no ar. Um exemplo de como esse medo é propagado pode ser encontrado no site do médico Dráuzio Varella, conhecido por sua participação num programa televisivo de grande audiência. Em entrevista sobre toxoplasmose publicada no site, o médico infectologista consultado sequer cita o consumo de verduras mal higienizadas como fonte de contaminação, mas ressalta várias vezes o risco da simples presença de gatos no ambiente:

Dráuzio - Como adquirimos esse parasita?

João Silva de Mendonça - Existem duas maneiras bem conhecidas de aquisição do Toxoplasma gondii. Uma delas ocorre em ambientes onde existam gatos, os grandes disseminadores do parasita na comunidade ambiental. Gatos infectados eliminam os ovos desse protozoário pelas fezes, poluem o ambiente e contaminam quem por ali circula. Não é necessário entrar em contato direto com eles, basta

\footnotetext{
${ }^{15}$ Em estudo com 364 ginecologistas-obstetras sobre medidas tomadas em relação à toxoplasmose, Jones et al (2001) observaram que as gestantes classificadas como arriscadas a contrair a doença eram identificadas da seguinte forma: $67 \%$ dos médicos apontaram a convivência com gatos, 30\% citaram o consumo de comida crua ou mal cozida, $12 \%$ mencionaram o contato com as caixas de areia dos gatos e $9 \%$ citaram a prática de jardinagem. Cenário semelhante foi encontrado no Brasil. Em estudo com 420 gestantes em Minas Gerais, Carellos, Andrade \& Aguiar (2008) identificaram que a proporção de mulheres informadas em relação ao gato como fator de risco foi de $95 \%$, enquanto somente $70 \%$ foram informadas sobre o risco de consumir carne crua e 53\% sobre a possibilidade de contaminação pelo consumo de hortaliças cruas inadequadamente higienizadas.
} 
dividir os mesmos espaços. Imaginemos, por exemplo, alguém que detesta gatos e vai visitar um amigo que tem um animal desses em casa, mas que o tranca em outro aposento para que nem chegue perto do visitante. No entanto, ele se senta numa poltrona onde o gato esteve deitado e sem querer leva a mão à boca. Pronto, está fechado o circuito microscópico: a partir da poluição ambiental provocada pelo gato, o parasita infectou o ser humano ${ }^{16}$ (Varella, 2011).

Além da toxoplasmose, os gatos são comumente associados à alergia (entendida como transmissível), asma, dermatites e problemas neurológicos (por aspiração de pelos que supostamente poderiam chegar ao cérebro). A repulsa motivada pelo medo foi um dado marcante na pesquisa de campo. Em quase todos os eventos de adoção em que foi feita a observação participante, foi possível presenciar alguma cena de rejeição, desde caretas, seguidas de afastamento em relação às gaiolas dos felinos, até expressões de repulsa declarada como “afe, só tem gato" ou “não, gato não! Deus me livre!” Entre os diálogos registrados, dois podem ser destacados pela extensão do medo e pelo desfecho de frustração pela incapacidade de "eliminar" a emoção negativa sentida pelas pessoas:

\begin{abstract}
Uma mulher, com cerca de 40 anos, contou que estava pensando em adotar um cachorro e, ao falar de sua rotina com muito tempo fora de casa, recebeu de mim a sugestão de que talvez um gato se adaptasse melhor. A mulher respondeu com uma expressão de surpresa e me disse que não queria um gato. Em seguida complementou que não fazia mal a eles, mas queria ficar longe dos gatos, porque tinha medo. Ri e expliquei que gatos não atacavam pessoas e que eram animais dóceis, ela explicou que seu medo era pegar doença, por isso quando ia à casa de uma amiga que tinha um gato, sempre batia o pé no chão e fazia sons para afastá-lo (shhhh, shhhh), porque tinha medo que ele se esfregasse em sua perna. Quando perguntei que doença ela achava que pegaria com isso, a mulher respondeu que "a doença do gato". Passei cerca de $15 \mathrm{~min}$ explicando como a toxoplasmose era transmitida e a mulher, surpresa com a chuva de informações, parecia incrédula. Abri uma gaiola, dei um beijo no gato que estava dentro e falei "viu? Não tem nada!" A mulher fez uma expressão de espanto e riu. Despediu-se de mim agradecendo "a aula" e dizendo que achava que não espantaria mais o gato da amiga - mas também não parecia nem um pouco inclinada a tocá-lo.
\end{abstract}

16 Essa forma de contaminação exigiria que o animal carregasse fezes contaminadas nos pelos, depositasse-as na poltrona e, naquele local, houvesse um ambiente quente e úmido para os oocistos esporularem. Em seguida, a pessoa precisaria colocar a mão no lugar exato em que isso houvesse ocorrido e, então, levasse a mão à boca. Essa conjunção de fatores é ainda mais improvável quando se considera o hábito que os gatos têm de se lamber várias vezes ao dia, removendo a sujeira dos pelos. 
O segundo caso aconteceu no evento de adoção realizado durante a Exposição Nordestina de Animais de 2013, um evento voltado para animais "de produção" que, portanto, reúne muitas pessoas do interior do estado e/ou afeitas ao ambiente rural.

\begin{abstract}
Um homem, com cerca de 60 anos, afirmou, com bastante certeza, que os pelos do gato eram perigosos porque poderiam ser aspirados e se alojar no cérebro. Foi necessário explicar sobre a função dos pelos no nariz humano e dos espirros e, em seguida, o destino do ar e das partículas aspiradas pelo sistema respiratório para que ele acreditasse que aquilo não era possível. A postura final de meu interlocutor foi de que, por via das dúvidas, era melhor ter cuidado porque, mesmo que não fosse para o cérebro, o pelo dos gatos poderia transmitir muitas doenças.
\end{abstract}

É interessante ressaltar que histórias assim dificilmente são ouvidas sobre os pelos dos cães. Seja por inexperiência com felinos, seja pelas representações negativas sobre essa espécie, o fato é que os riscos a eles associados costumam ser majorados em relação àqueles atribuídos aos cães, ainda estes sejam o alvo prioritário das políticas institucionais de extermínio como prevenção à raiva. Além disso, não foram observadas expressões de repulsa a cães, apenas alguns gestos de medo de agressão. De acordo com Osório (2010), os gatos possuem um status ambíguo (parcialmente domésticos e parcialmente selvagens) e sua representação como "independentes e traiçoeiros" reforça a distância socialmente construída entre eles e nós.

\title{
A animalidade como problema
}

A percepção da superpopulação de animais em situação de rua como problema de saúde pública é uma condição ambígua presente nos centros urbanos, pois serve de argumento tanto para os que defendem a sua eliminação quanto para os que defendem investimentos em sua proteção. Essa ambiguidade fica especialmente explícita quando protetores de animais participam da redação de projetos de lei, pedidos de financiamento ou mesmo pautas para a imprensa. Em todos esses casos, é considerado eficaz, para receber atenção, afirmar que a realização de controle populacional e de cuidados com a saúde dos animais é questão de saúde pública, como já destaca Matos (2012). Assim, a transmissão de zoonoses é posta em foco e os animais de estimação com acesso à rua (domiciliados ou não) são apresentados como transmissores em potencial. Por outro lado, com receio de estimular maus tratos e envenenamentos por 
medo de zoonoses, os mesmos protetores sentem a necessidade de reduzir ou negar o risco de qualquer transmissão quando dialogam com o público mais amplo. Além disso, sentem-se ofendidos quando algum órgão estatal ou da mídia trata os animais de estimação como transmissores de doenças. Para os protetores de animais, as informações sobre zoonoses são tratadas como argumento retórico que deve ser enfatizado apenas na justificativa de projetos e relatórios.

Diante do temor de que animais sejam maltratados ou abandonados como forma de prevenir doenças, a reação inicial dos protetores é negar a possibilidade de transmissão e, se o assunto persistir, sublinhar os hábitos de higiene e os cuidados com a saúde do animal como determinantes na ocorrência ou não de contaminação, em detrimento do contato com os animais. Mais uma vez, os comentários de internautas em matérias sobre zoonoses dão uma mostra interessante:

C. (mulher) - gostei do texto, bem explicadinho. lavar a mão quando chega da rua, lavar a mão quando brinca com o gato ou cachorro,, ter as vacinas em dia, e não deixar o gato solto para não pegar doenças, felino é um caçador e pode matar um rato ,pombo, etc e pegar doença. lugar de gato é dentro de casa, brincando com seu brinquedinhos, dormindo, comendo ração, agua limpinha e sua caixinha de areia sempre limpa. se fizermos tudo certinho não tem doença, pq como diz o texto ate uma carne mal passada causa doença.

M.A (homem) - O cão ou gato somente transmitirá doenças se estes estiverem doentes. Se você cuidar bem do seu animalzinho, levar periodicamente ao veterinário, vermifugar, passar todo mês anti-pulgas e carrapatos, não esquecer das vacinações, ter cuidados com a higienização do animal, ele não vai ter nenhuma doença para transmitir. Por essa lógica da matéria também não podemos dormir com nosso cônjuge, pois humanos também transmitem um monte de doenças.

A prevenção às zoonoses é atribuída a uma combinação de cuidado e controle, que inclui a alimentação com rações e o impedimento do acesso à rua. Responsabilizando as pessoas pela manutenção de sua saúde, a moralidade de proteção parte para um contra-ataque.

A sensibilidade de empatia interespécie tem se desenvolvido inicialmente em pequenos grupos das camadas médias dos centros urbanos, mas suas consequências alcançam camadas mais amplas da população. O principal exemplo disso é o enrijecimento do controle normativo sobre as relações com cães e gatos, que tem sido imposto não tanto pelo Estado, e sim por indivíduos que assumem o papel de empreendedores morais e passam a vigiar e denunciar uma variedade de situações 
entendidas como maus tratos. Essa tendência de vigiar, denunciar e intervir nas relações alheias com cães e gatos pode ser apontada como característica dos membros da proteção animal, mas não se restringe aos ativistas.

A configuração social aqui descrita reforça as conexões entre a moralidade de proteção e a moralidade de parentesco, gerando aproximações entre os animais membros da família e os animais abandonados. O próprio crescimento e visibilidade dos animais resgatados e dos eventos de adoção nas redes sociais e na mídia fazem com que um número crescente de animais membros da família seja proveniente de resgates, levando os tutores a classificarem os animais em situação de rua como muito próximos daqueles com os quais partilham os ambientes íntimos da casa. Além disso, com o crescimento dos grupos de proteção animal, as histórias de animais resgatados passaram a ser divulgadas com frequência nas redes sociais e na mídia. Diante disso, a ideia de interagir ou mesmo de resgatar um animal da rua, embora permaneça assustadora para muitos, ganhou o status de uma redenção mútua - para o animal salvo e para a pessoa, entendida como alguém melhor a partir desse momento.

A redução da distância entre os animais em situação de rua e os domiciliados foi traduzida juridicamente na criação da categoria "animal comunitário", presente na legislação dos estados de Pernambuco, Rio Grande do Sul, Paraná, São Paulo e Rio de Janeiro. Com pequenas distinções, essas leis definem animal comunitário como "aquele que estabelece com a comunidade em que vive laços de dependência e de manutenção, ainda que não possua responsável único e definido" "17. Ao analisar a lei que estabeleceu a categoria animal comunitário no Rio de Janeiro, Osório percebe que:

Em uma lauda sucinta, fica claro que: os animais de rua não devem ser necessariamente recolhidos das ruas e que, portanto, têm o direito de se manter nos espaços públicos onde estão; que sobrevivem do contato com a população local, que não necessariamente quer a sua retirada do local e que, direta ou indiretamente, contribuem para sua manutenção; que têm direito a atendimento veterinário, apesar de não terem proprietário único ou específico; que perante a burocracia estatal ambos, animal e protetor, devem ser cadastrados e monitorados; por último, que é responsabilidade do Estado regular a relação entre protetores e suas colônias (Osório, 2013: 167-168).

\footnotetext{
${ }^{17}$ Em São Paulo, a categoria foi criada pela lei 12.916/2008; no Rio Grande do Sul, pela 13.193/2009; Em Pernambuco, pela 14.138/2010; no Paraná, pela lei 17422/2012; Rio de Janeiro pela lei 6464/2013.
} 
É importante destacar que, em todas essas leis, para que seja reconhecido como comunitário e tenha sua permanência garantida no local em que se estabeleceu, o animal deve ser castrado e registrado no nome de um cuidador principal. Ao mesmo tempo que protege a sensibilidade civilizada da ideia de extermínio e conquista o apoio de uma parcela da população interessada em protegê-los, essa tipificação legal dá ao Estado a possibilidade de castrar, vacinar e devolver os animais para o local em que estavam sem ser acusado de estar abandonando. Além disso, a nomeação de um cuidador principal tende a gerar entre as pessoas uma sensação de responsabilidade sobre o animal, que favorece a realização do controle sobre sua saúde, comportamento e vacinação.

A partir dos dados apresentados, percebemos que existe, do ponto de vista do debate sobre os animais não humanos no espaço público, uma disputa entre as formas civilizadas, estabelecidas ao longo do século XX, baseadas nas formas do medo e ansiedade coletivos, e uma sensibilidade de empatia interespécie em desenvolvimento, mais especificamente na expressão de uma moralidade de proteção, organizada em torno do valor altruísmo, que tem os animais abandonados como prioridade. Sabemos da existência de outros ordenamentos morais relevantes, mas ressaltamos esses dois como os modelos centrais que organizam a agenda e o debate recente sobre o problema da presença dos animais não humanos no espaço público.

Não afirmamos uma oposição entre essas duas formas, mas uma tensão. Os impulsos civilizatórios são componentes da configuração em que emerge essa sensibilidade a partir da qual o sofrimento e a morte de espécies não humanas passam a causar desconforto e levantar questões morais. Ao mesmo tempo, porém, a civilidade é marcada pelo impulso de afastar-se da animalidade, responsável pelo surgimento de emoções negativas em relação aos aspectos biológicos de nosso organismo. Surge, então, uma situação paradoxal, pois, ao mesmo tempo em que o impulso de condenação à violência tem se expandido e incluído animais não humanos no círculo de seres a serem protegidos, a convivência com esses animais nos obriga a encarar diversos aspectos da animalidade que são repugnantes à sensibilidade civilizada. Dessa maneira, animais soltos nas cidades geram uma dupla ansiedade, pois são vistos a um só tempo como vítimas vulneráveis a ações crueis e como causadores de incômodo (fonte de doença, barulho, sujeira, lixo rasgado, acidentes de trânsito e agressões). 
Se considerássemos apenas o modelo teórico, seríamos tentadas a descrever essas duas moralidades na relação com os animais (civilizada e de proteção) como um processo de ruptura entre dois tipos historicamente situados. Nessa explicação, as moralidades fundamentadas na empatia com os animais, marcadas especificamente pela recusa das formas de dominação e afirmação da superioridade de uma espécie sobre as outras, substituiria a moralidade civilizada que, apesar de sua importância histórica na diminuição do sofrimento, é ainda baseada no cuidado com os sentimentos humanos. Esse modelo poderia ser fundamentado no desenvolvimento recente da ética animal e na centralidade política e moral da rejeição de formas estabelecidas de hierarquização das espécies. Ainda, um tal modelo pareceria adequado a uma leitura corrente da pesquisa eliasiana que percebe o processo civilizador como um aumento progressivo e simples nas formas de autocontrole e, desse modo, a intensificação do nojo e do medo que protegem as formas civilizadas estariam dando lugar a formas mais radicais de respeito aos animais. Contudo, apesar da tentação de confirmação teórica, a experiência analisada não permite essa interpretação.

Como já afirmamos acima, a relação entre a moralidade civilizada (que submete o trato dos animais não humanos ao bem-estar dos humanos) e a moralidade de proteção (pela qual se busca estabelecer o direito dos animais em si, sem subordinação aos interesses humanos) é ambígua e conflituosa, não permitindo a construção de um modelo simples de oposição. Sendo assim, três pontos preicsam ser sublinhados. Primeiro, é preciso destacar que, apesar da violência manifesta em muitas das realizações da sensibilidade civilizada, os seus ideias de tratamento humanitário, quando percebidos segundo formas de interação, representam um ganho moral, ao evitarem formas de tratamento crueis e degradantes. Em segundo lugar, os termos que organizam normativamente o modo civilizado não excluem a forma altruísta ou de proteção. $\mathrm{O}$ ideal de bem-estar de humanos e animais que organiza a moralidade civilizada permite um trânsito ou elo entre as duas formas que, do ponto de vista da civilidade, não é contraditório. Do ponto de vista dos fundamentos de uma ética animal que organiza a moralidade de proteção, há, porém, uma contradição: o foco civilizado no bem-estar, ainda que represente um tratamento mais digno para os animais, é uma concessão inviável, visto que se baseia ainda na superioridade e poder de determinação humanos. Apesar dessa evidente diferença entre as moralidades civilizada e de empatia, o terceiro ponto que destacamos para confirmar a ambiguidade presente na relação entre os dois 
modelos normativos é o processo discutido a partir do caso empírico da Região Metropolitana do Recife. $\mathrm{Na}$ análise aqui realizada, percebemos que, apesar de rejeitarem sistematicamente uma série de valores civilizados no trato dos animais de estimação, os protetores fazem uso estratégico da hegemonia do medo civilizado para garantir o estabelecimento de suas formas de moralidade empática, reafirmando o trânsito ou conexão entre os dois modos. Por fim, destacamos o fato de que as discordâncias entre fundamentos normativos não refletem necessariamente em discordâncias práticas. Como destacamos no debate sobre a prevenção às zoonoses via esterilização e medidas de controle, é possível que haja uma concordância em termos das ações requeridas ou uma aproximação momentânea entre os interesses de bem-estar de humanos e não humanos.

A partir disso, acreditamos que o caso estudado é relevante para o debate sociológico e antropológico sobre as relações interespecíficas, por indicar que os modelos normativos ou as discussões mais gerais sobre valores morais precisam ser confrontadas com as formas da experiência. Ainda nesse sentido, acreditamos que, mais que uma crítica, o caso da proteção em Recife e seu debate sobre o lugar dos animais no espaço público confirma a perspectiva da sociologia figuracional e seu foco nas redes de interações como elemento fundamental na compreensão de processos sociais. No caso estudado, claramente encontramos um conjunto de interações que diferem da tendência principal no processo civilizador da relação com os animais, mas ainda não é possível definir em que sentido se dá esse desvio. A ordenação moral das relações com animais não humanos no espaço público ainda é determinada de forma mais intensa pelo modo civilizado, mas a sensibilidade de empatia vem, aos poucos, assumindo importância no cenário e problematizando os modos estabelecidos. Mesmo que seja possível afirmar, do ponto de vista do reconhecimento das espécies e da recusa do sofrimento, uma maior abertura para a experiência ética nos argumentos da proteção animal, a construção da moral é uma prática e se dá nas interações entre grupos viariados.

Assim, mais que a preocupação com a direção do processo civilizador, é importante destacar a figuração e, especialmente, a importância sociológica de se tratar as disputas de valores como confrontos práticos em figurações específicas. No caso da sociologia figuracional e, particularmente, da lógica do processo civilizador para compreensão da vida moral, temos a vantagem de que esse foco na interação não significa uma adoção de relativismo radical, mas um modelo capaz de perceber a tensão 
entre valores universais - ou, dito sociologicamente, que tentam se universalizar (como as propostas que se colocam como fundamento para uma ética animalista) - e seus momentos particulares.

Diante desse quadro, percebemos que construção da normatividade que rege as relações entre humanos e não humanos no espaço público vive um momento de tensão em que a forma universalizada de controle civilizado vem sendo confrontada por uma outra lógica de pretensões universais - a forma moral da empatia. O nosso argumento, baseado no caso particular da proteção animal na cidade do Recife, buscou demonstrar que essa disputa se desenvolve não como um debate teórico em que se pesa valores em si, mas como uma forma prática, ordenada de acordo com as dificuldades e limites resultantes da disputa entre projetos ético-políticos de convivência.

\section{Referências}

APROBATO FILHO, Nelson. O Couro e o Aço: sob a mira do moderno: a "aventura" dos animais pelos "jardins" da Paulicéia, final do século XIX/início do século XX. Tese de doutorado (História Social). Universidade do Estado de São Paulo, São Paulo, 2006

BABBONI, S. D.; MODOLO, J. R. Raiva: Origem, Importância e Aspectos Históricos. UNOPAR Cient Ciênc Biol Saúde, v. 13, n. Esp, p. 349-356, 2011.

BOLTANSKI, L.; THÉVENOT, L. The sociology of critical capacity. European journal of social theory, v. 2, n. 3, p. 359-377, 1999.

BOLTANSKI, L.; THÉVENOT, L. On Justification: Economies of Worth.NJ: Princeton University Press, 2006.

BRAGA JR, A. X. et al. Panorama geral sobre a proteção animal em Recife: relatório parcial de avaliação, realizado como atividade da disciplina Métodos Avançados em Pesquisa Quantitataiva. Recife/PE. 2011

BRASIL. Guia de Vigilância Epidemiológica $7^{\text {a }}$ edição Série A. Normas e Manuais Técnicos. Caderno 13. Brasília, Ministério da Saúde, 2009

BRASIL. Sistema nacional de vigilância em saúde: relatório de situação Pernambuco. Brasília, Ministério da Saúde, 2011

CARELlOS, E. V. M.; ANDRADE, G. M. Q.; AGUIAR, R. Avaliação da aplicação do protocolo de triagem pré-natal para toxoplasmose em Belo Horizonte, Minas Gerais, Brasil: estudo transversal em puérperas de duas maternidades. Cad Saúde Pública, v. 24, n. 2, p. 391401, 2008.

CAVALHEIRO, T. K. A (in) constitucionalidade da lei das carroças do município de Porto Alegre. Porto Alegre (RS): Universidade Federal do Rio Grande do Sul, 2014.

CORTEZ, T. L. Raiva urbana: epidemiologia e controle. Dissertação (Mestrado em Medicina Veterinária) Universidade Estadual Paulista (UNESP), 2006.

ELIAS, N. O Processo Civilizador 2: formação do Estado e civilização. Rio de Janeiro, Zahar, v. 2, 1993.

ELIAS, N. A Sociedade dos Indivíduos. Rio de Janeiro: Jorge Zahar, p. 201, 1994.

ELIAS, N. Os alemães: a luta pelo poder e a evolução do habitus nos séculos XIX e XX. Rio de Janeiro, Zahar, 1997.

ELIAS, N. Sobre o tempo. Rio de Janeiro: Zahar, 1998.

ELIAS, N. A Solidão dos Moribundos. Rio de Janeiro, Zahar, 2001.

ELIAS, N. O processo civilizador: uma história dos costumes. Rio de Janeiro, Zahar, v. 1, 2011. ELMORE, S. A. et al. Toxoplasma gondii: epidemiology, feline clinical aspects, and 
prevention. Trends in parasitology, v. 26, n. 4, p. 190-196, 2010.

GODINHO, P. R. "Pedigree" brasileiro. Revista de História da Biblioteca Nacional, v. $\mathrm{n}^{\mathrm{o}}$ 60, 2010.

HEYNEMANN, C. B. Da natureza para a cultura. Revista de História da Biblioteca Nacional, v. $n^{\circ} 60,2010$.

JONES, J. et al. Survey of obstetrician-gynecologists in the United States about toxoplasmosis. Infectious diseases in obstetrics and gynecology,v.9,n.1,p.23-31, 2001

LAWRENCE, E. A. Conflicting ideologies: Views of animal rights advocates and their opponents. Society and Animals, v. 2, n. 2, p. 175-190, 1994.

LIMA, M. H.C.C.A. Animais de estimação e civilidade: a sensibilidade de empatia interespécie nas relações com cães e gatos. Tese de doutorado [Sociologia] Universidade Federal de Pernambuco. Recife, 2016.

LIMA, M. H. C. C.; SILVA NETTO, G. DA M. Significação de animais não-humanos e legislação de controle populacional. II Congresso Mundial de Bioética e Direito Animal. Anais...Salvador: 2010

MACIEL, K. P. Inquérito sorológico para detecção de anticorpos de Toxoplasma gondii em caprinos (Capa hircus) criados nos municípios de Gravataí e Viamão, Região da Grande Porto Alegre, Rio Grande do Sul, Brasil. Dissertação (Mestrado em Medicina Veterinária). Universidade Federal do Rio Grande do Sul., 2004.

MATOS, Liziane Gonçalves de. Quando a "ajuda é animalitária" - um estudo antropológico sobre sensibilidades e moralidades envolvidas no cuidado e proteção de animais abandonados a partir de Porto Alegre, RS. Dissertação (Mestrado em Antropologia), PPGAS-UFRGS, Porto Alegre, 2012.

MIRANDA, Cristina; LADENDORFF, Nádia; KNÖBL, Terezinha. Percepção da população sobre a participação dos pombos (Columba livia domestica) na transmissão de zoonoses. Atas de Saúde Ambiental-ASA, v. 2, n. 1, p. 23-28, 2014.

MONTEIRO et al. Impactos da Toxoplasmose na Saúde Pública. Boletim Informativo DMVP/UFSM - ano 6. edição 2012 pp. 2-11, 2013

OMS. O controle da raiva - Oitavo relatório do Comitê de Especialistas da OMS em Raiva. Goiânia: Editora da UFG, 1999.

OSÓRIO, Andréa. Alguns aspectos simbólicos acerca do gato. Ilha Revista de Antropologia, v. 12, n. 1, 2, p. 233-259, 2010.

OSÓRIO, Andréa. A cidade e os animais: da modernização à posse responsável. Revista Teoria \& Sociedade, $\mathrm{n}^{\mathrm{o}} 21.1$ - janeiro-junho pp. 143-176, 2013

REGAN, T. Jaulas Vazias: encarando o desafio dos direitos animais. Porto Alegre, RS: Lugano, 2006.

REZENDE, J. M. À sombra do plátano: crônicas de história da medicina. São Paulo: Editora Unifesp, 2009.

RITVO, H. Animals In Nineteenth-Century Britain: Complicated Attitudes And Competing Categories. In: MANNING, A.; SERPELL, J. (Eds.). Animals and human society: changing perspectives. New York: Routledge, 2003.

SCHEFF, T. Elias, Freud and Goffman: shame as the master emotion. In: LOYAL, S. \& QUILEY, S. (Ed). The Sociology of Norbert Elias. Cambridge: Cambridge University Press, 2004

SENNETT, R. O declínio do homem público: as tiranias da intimidade. São Paulo: Cia das Letras, 1988

SERPELL, JAMES A \& PAUL, E. Pets and the development of positive Attitudes to animals. In: SERPELL, A. M. AND J. (Ed.). Animals and human society: changing perspectives. New York: Taylor \& Francis e-Library, 2003.

SILVA, C. C. Pesquisa de anticorpos anti-Toxoplasma gondii (Nicolle \& Manceaux, 1909) em felídeos selvagens nos municípios de Capitão Poço e Belém, Pará. Dissertação (Mestrado em Ciência Animal). Universidade Federal do Pará, 2008

SILVEIRA, Flávio L. Abreu da. De um Prosaico Coexistir Interespecífico aos Dilemas do Biopoder: as interações humanas e não humanas no mundo urbano contemporâneo amazônico. 
Ilha Revista de Antropologia, v. 17, n. 1, p. 55-81, 2015.

SINGER, P. Libertação Animal. Cidade do Porto, Portugal. 2008.

THOMAS, K. O homem e o mundo natural: mudanças de atitude em relação às plantas e aos animais (1500-1800). São Paulo: Companhia das Letras, 2010.

WHO - WOLRD HEALTH ORGANIZATION (WHO/OMS). Rabies peophylaxis. $5^{\text {a }}$ Session of Executive Board, Fifth Session. 1949.

WORLD HEALTH ORGANIZATION (WHO/OMS). Expert Committee on Rabies, Sixth Report. Technical Report Series. Geneva, 1973. Disponível em: <http://apps.who.int/iris/bitstream/10665/38621/1/WHO_TRS_523.pdf>.

WHO - WORLD HEALTH ORGANIZATION (WHO/OMS). Report of WHO consultation on dog ecology studies related to rabies control. Geneva, 1988.

WHO - WORLD HEALTH ORGANIZATION et al. Guidelines for Dog Population Management. Geneva, 1990.

\section{Jornais, sites e revistas}

ADA - ATIVISTAS PELOS DIREITOS DOS ANIMAIS. Recife contra a carrocinha. Disponível em: <https://recifecontraacarrocinha.wordpress.com/>.Acesso:1 abr. 2012.

ALBUQUERQUE, Beatriz. Seda, uma pasta questionada da Prefeitura do Recife. Jornal do Commercio, 03 de novembro de 2013.

BLOG DE JAMILDO. No Recife, ativistas protestam contra atuação da Secretaria de Defesa Animal. Blog de Jamildo, 04 de junho de 2013. Disponível em: http://m.blogs.ne10.uol.com.br/jamildo/2013/06/04/no-recife-ativistas-protestam-contraatuacao-da-secretaria-de-defesa-animal/ Acessado em outubro de 2016

BRAGA, Carolina. Protetores criticam atuação da Secretaria-Executiva de Direitos dos Animais. Diario de Pernambuco, 13 de novembro de 2014.

BRITO, Noelia. Por que a SEDA de Geraldo Júlio ainda continua sedada. Blog do Jamildo, 26 de novembro de 2013. Disponível em: http://blogs.ne10.uol.com.br/jamildo/2013/11/26/porque-a-seda-de-geraldo-julio-ainda-continua-sedada/ Acessado em outubro de 2016

BRITO, Noelia. Conselho Gestor do Centro de Vigilância Ambiental denuncia SEDA ao Ministério Público Federal. Blog do Jamildo, 21 de janeiro de 2014. Disponível em: http://blogs.ne10.uol.com.br/jamildo/2014/01/21/quando-a-participacao-popular-faz-a-

diferenca-conselho-gestor-do-cva-denuncia-seda-ao-mpf/ Acessado em outubro de 2016

CÃES \& COMPANHIA. No 48 ed. São Paulo (SP): Editora Flash, 1983a.

CÃES \& COMPANHIA. N 51 ed. São Paulo (SP): Editora Flash, 1983b.

DIARIO DE PERNAMBUCO. Entidades de defesa dos animais se reúnem em frente à Prefeitura do Recife para cobrar ações da SEDA. Diario de Pernambuco, 24 de fevereiro de 2015.

LEIA JÁ. "Vidal nunca se preocupou com os animais, acusa ex-acessor". Leia Já, 20 de março de 2015. Disponível em: http://pernambuco.ig.com.br/noticias/2015/vidal-nunca-se-preocupoucom-animais-acusa-ex-assessor Acessado em outubro de 2016

LEIA JÁ. Projeto Mascote de Rua rebate informações da SEDA. Leia Já, 01 de julho de 2015. Disponível em: http://pernambuco.ig.com.br/noticias/2015/projeto-mascote-de-rua-rebateinformacoes-da-seda Acessado em outubro de 2016.

Recebido em: 29/10/2016.

Aprovado em: 02/12/2016. 